This article was downloaded by: [192.87.139.139]

On: 06 February 2012, At: 07:16

Publisher: Routledge

Informa Ltd Registered in England and Wales Registered Number: 1072954 Registered office:

Mortimer House, 37-41 Mortimer Street, London W1T 3JH, UK

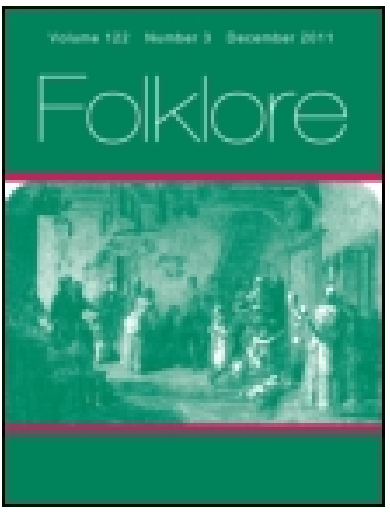

\title{
Folklore
}

Publication details, including instructions for authors and subscription information:

http://www.tandfonline.com/loi/rfol20

\section{In Search of the Dutch Lore of the Land: Old and New Legends throughout the Netherlands}

Theo Meder

Available online: 24 Jun 2011

To cite this article: Theo Meder (2011): In Search of the Dutch Lore of the Land: Old and New Legends throughout the Netherlands, Folklore, 122:2, 117-134

To link to this article: http://dx.doi.org/10.1080/0015587X.2011.570501

PLEASE SCROLL DOWN FOR ARTICLE

Full terms and conditions of use: http://www.tandfonline.com/page/terms-and-conditions

This article may be used for research, teaching, and private study purposes. Any substantial or systematic reproduction, redistribution, reselling, loan, sub-licensing, systematic supply, or distribution in any form to anyone is expressly forbidden.

The publisher does not give any warranty express or implied or make any representation that the contents will be complete or accurate or up to date. The accuracy of any instructions, formulae, and drug doses should be independently verified with primary sources. The publisher shall not be liable for any loss, actions, claims, proceedings, demand, or costs or damages whatsoever or howsoever caused arising directly or indirectly in connection with or arising out of the use of this material. 


\title{
In Search of the Dutch Lore of the Land: Old and New Legends throughout the Netherlands [1]
}

\author{
Theo Meder
}

\begin{abstract}
Inspired by The Lore of the Land, published by Jennifer Westwood and Jacqueline Simpson in 2005, a Dutch version of this book, comprising local and regional legends, was published in the Netherlands in 2010 by Willem de Blécourt, Ruben Koman, Jurjen van der Kooi, and Theo Meder. The editors selected over three hundred and fifty legends, representative of the twelve provinces of the Netherlands, for the volume. Some were real ecotypes, having been appropriated by local communities and having led to the erection of associated statues, often for touristic and commercial purposes, as well as for shaping collective identities, while others were almost forgotten tales. The editors also found, somewhat unexpectedly, that quite a number of popular legends had been composed and constructed by romantic writers in the nineteenth century, and that these older legends were much more popular than the recently-invented ones. As the editors also included a number of contemporary legends, they discovered that one such legend had already become popular enough to have a statue erected and a song composed in its honour.
\end{abstract}

\section{Introduction}

The publication The Lore of the Land. A Guide to England's Legends, from SpringHeeled Jack to the Witches of Warboy (2005) by Jennifer Westwood and Jacqueline Simpson was a great success (compare Simpson 2008). This richly illustrated book, containing over nine hundred pages, deals with the lore, but particularly with the legends of all the counties of England. The many legends included deal with all kinds of saints and devils, wizards and witches, giants and dwarfs, fairies and mermaids, robbers and ghosts. Well-known legendary characters such as King Arthur, Merlin the Magician, Saint George, and Robin Hood, are represented, as well as landscape phenomena, such as Stonehenge and the Cerne Abbas Giant.

In 2006, along with some co-editors and authors, I decided to compile a Dutch "Lore of the Land," in order to put our legends, representative of the Netherland's twelve provinces, on the map, so to speak. It was also possible to include Friesland with its own language, since one of our co-editors, Jurjen van der Kooi, is a Frisian oral narrative specialist. It was clear to me and to the co-editors Jurjen van der Kooi, Ruben A. Koman, and Willem de Blécourt [2] that it would not be too difficult to find and comment on about thirty places within each province, with an associated local legend-except for the newest province, Flevoland, which mainly consists of twentieth-century reclaimed land, with only a few and very recent cities. Three former and now incorporated islands, Urk, Schokland and Nagele, had to provide the traditional legends for the province of Flevoland. 
The book containing local legends, Verhalen van Stad en Streek; Sagen en Legenden in Nederland [Tales from Town and County; Legends in the Netherlands ], [3] arose from an ongoing project entitled "Communities Claiming Tales," the object of which is to carry out research on local groups and communities who claim legends (mostly migratory) as their own, or who appropriate them to themselves. We call these legends ecotypes; that is, stories circulating in the oral tradition that become connected with local history, landscape, or heroes (Clements 1997; Von Sydow 1948). The book contains well-known and not-so-well-known traditional legends, and, in comparison with The Lore of the Land, the number of contemporary legends it includes is greater. [4]

Some legends are very closely connected to places. Sometimes, these stories continue to exist for a number of generations without any apparent assistance. But the survival of legends is not necessarily natural or spontaneous, as individuals or groups can set out to canonise a local tale. Such stories can be used to fulfil a commercial purpose, or be part of a tourist attraction, or of an idealised past. In some cases, traditional legends can be used to create or to stimulate local collective feelings of affinity and belonging, to stress one's cultural identity, or to represent a certain image of locality to the outside world.

Here I wish to present a few cases we encountered that may serve as an example of typical phenomena that can occur in respect of appropriated and exploited ecotypes. [5] Processes and phenomena of interest in this context are: appropriation (ranging from carefree importation to aggressive annexation), rivalry, incorporation and exclusion, self-representation, tourism, musealisation, festivalisation, dramatisation, commercialisation, iconisation, canonisation, authenticity, invention of tradition, and the dynamics of function and meaning.

An obvious claim on a story is made as soon as a community decides to erect a statue to it.

\section{Fiction from Abroad, Mainly for Foreign Tourists: Hans Brinker}

Abroad he is supposed to be the narrative icon of the Netherlands-below-sealevel, but Hans Brinker is, in fact, the creation of an American author, Mary Mapes Dodge (1831-1905). He is a fictional character in her children's novel Hans Brinker or the Silver Skates (Dodge 1865). The legend is about the boy who, during the night, saved the land from flooding by sticking his finger in a leaking dyke. The hero in a chapter in the novel entitled "The Hero of Haarlem" remains anonymous - the assumption that this heroic act should be attributed to the main character, Hans Brinker, is erroneous. Although the author herself claimed that the story was an old legend known by every Dutchman, this was not the case. [6] There was no trace in the Netherlands of a legend about a boy with his finger in a dyke or dune (shown on some illustrations) before the novel was published. In composing the legend of the boy with his finger in the dyke, Mapes Dodge was inspired by the literary tale "The Little Dutch Hero," which was published anonymously in the British Boy's Own Magazine in 1855 (Anonymous 1855). The story demonstrates no knowledge whatsoever of how Dutch dykes or dunes were constructed. A dyke is not like a brick wall in which a hole can be plugged by using one's finger in order to prevent the water from flowing in. Apart from that, the American story displays a form of heroism that appears to be rather 
non-Dutch, since heroes in Dutch legends are seldom triumphant winners, but rather tragic losers. However, in the period of the so-called "Holland Mania" in the USA (see Stott 1998), Americans idealised the Dutch as if they were noble, wild people-simple, content, hardworking, persistent, dutiful, and, above all, God-fearing. When American tourists visited the Netherlands after the Second World War, they were surprised to find no statue of the boy who had saved the Netherlands from being submerged. Eventually, in 1950, the Tourist Bureau of Spaarndam, a small village in the province of North Holland, near Haarlem, erected a statue to Hans Brinker (Figure 1). The statue is visited by busloads of tourists from the USA and Japan each year. The inscription on the statue is in Dutch, but there is also an English-language version with American-style spelling. The latter reads: "Dedicated to our youth, to honor the boy who symbolizes the perpetual struggle of Holland against the water." Meanwhile, the Dutch, too, got to know this symbolic boy with his finger in the dyke, and, after a considerable time-lag, the story finally became a Dutch legend also. [7] The legend is connected to Spaarndam, but only because of the existence of the statue, as this small village situated near Haarlem is nowhere near the sea.

\section{An "Early" and Doubtful Claim: Reynard the Fox}

Erecting a statue is thus a good means by which a community can appropriate or lay claim to a legend character. Most statues in the Netherlands were erected after

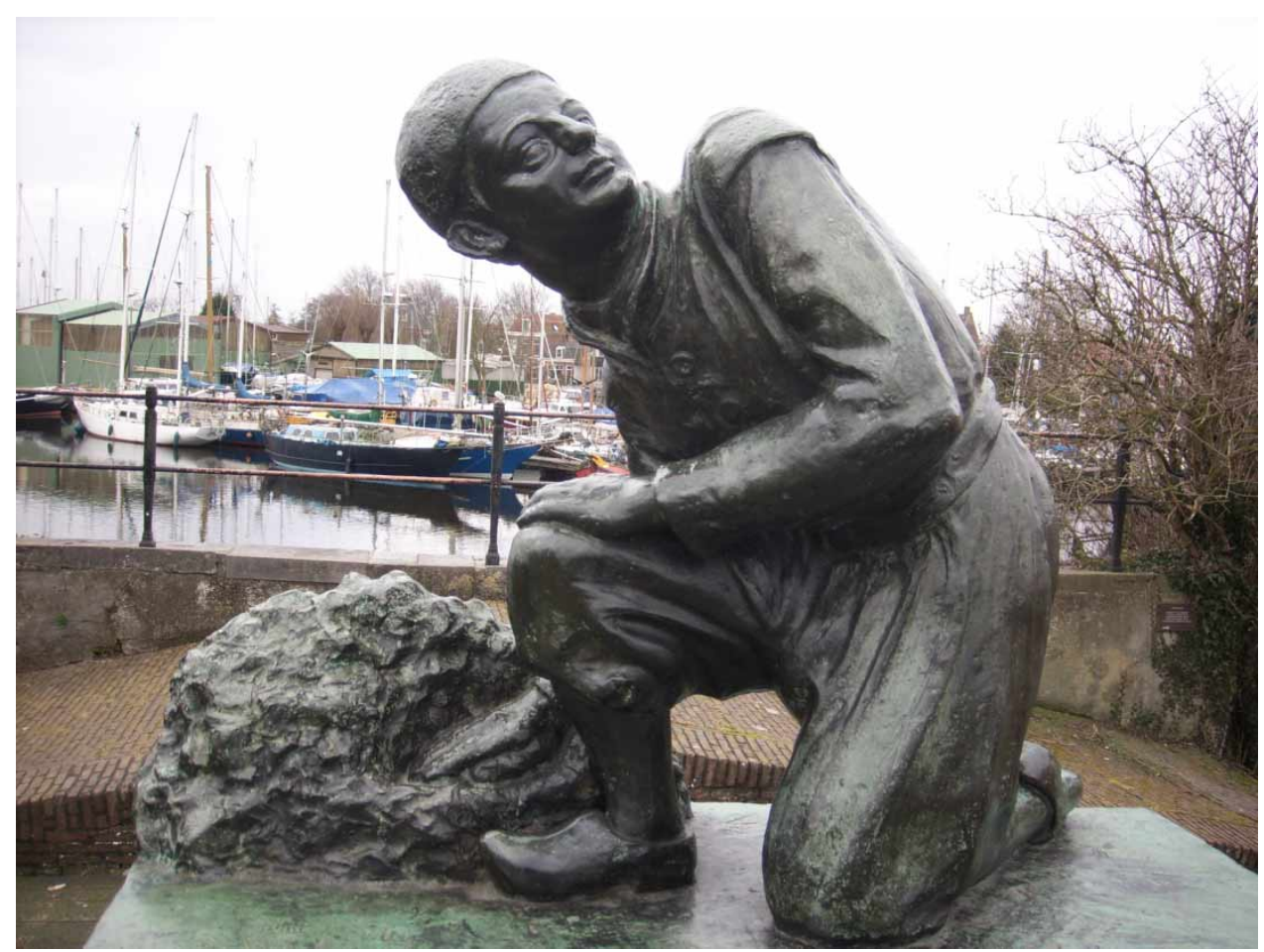

Figure 1. The statue of Hans Brinker in Spaarndam. Photograph: Ruben A. Koman. 
the Second World War. There is, however, one exception to this-a statue depicting Reynard the Fox as a penitent pilgrim before the court of King Nobel, which was placed in Hulst in Zeeland as early as 1938 (Figure 2). This occurred after some scholars suggested that not only was the forest of Hulst mentioned in the medieval epic tale, but that there was also a possibility that the entire animal epic had originated in that town. The local canonisation of Reynard continued after the Second World War when the number of statues, street names, and tourist routes in his honour increased, and when more and more processions, plays, and festivals dedicated to him were held. Furthermore, in support of its claim to Reynard the Fox, the municipality of Hulst even named a local pond "Kriekeputte" because such a place was also mentioned in the medieval animal tale. So in this way Hulst was turned into Reynard City. [8]

All of these processes of the folklorisation, musealisation, and festivalisation of Reynard in Hulst almost cause us to forget that the local claim on the Reynard character has hardly any basis in fact. Both the toponyms mentioned in the tale and the language of the poet point to East Flanders in Belgium as the landscape of the Reynard epic. The forest of Hulst is mentioned merely as a far-away place in a lie composed by Reynard about a conspiracy against the king. Still, even though proof is scant, nobody in Hulst, or in the Netherlands for that matter, seems to feel particularly uneasy about the fact that Hulst appropriated the fox's tale.

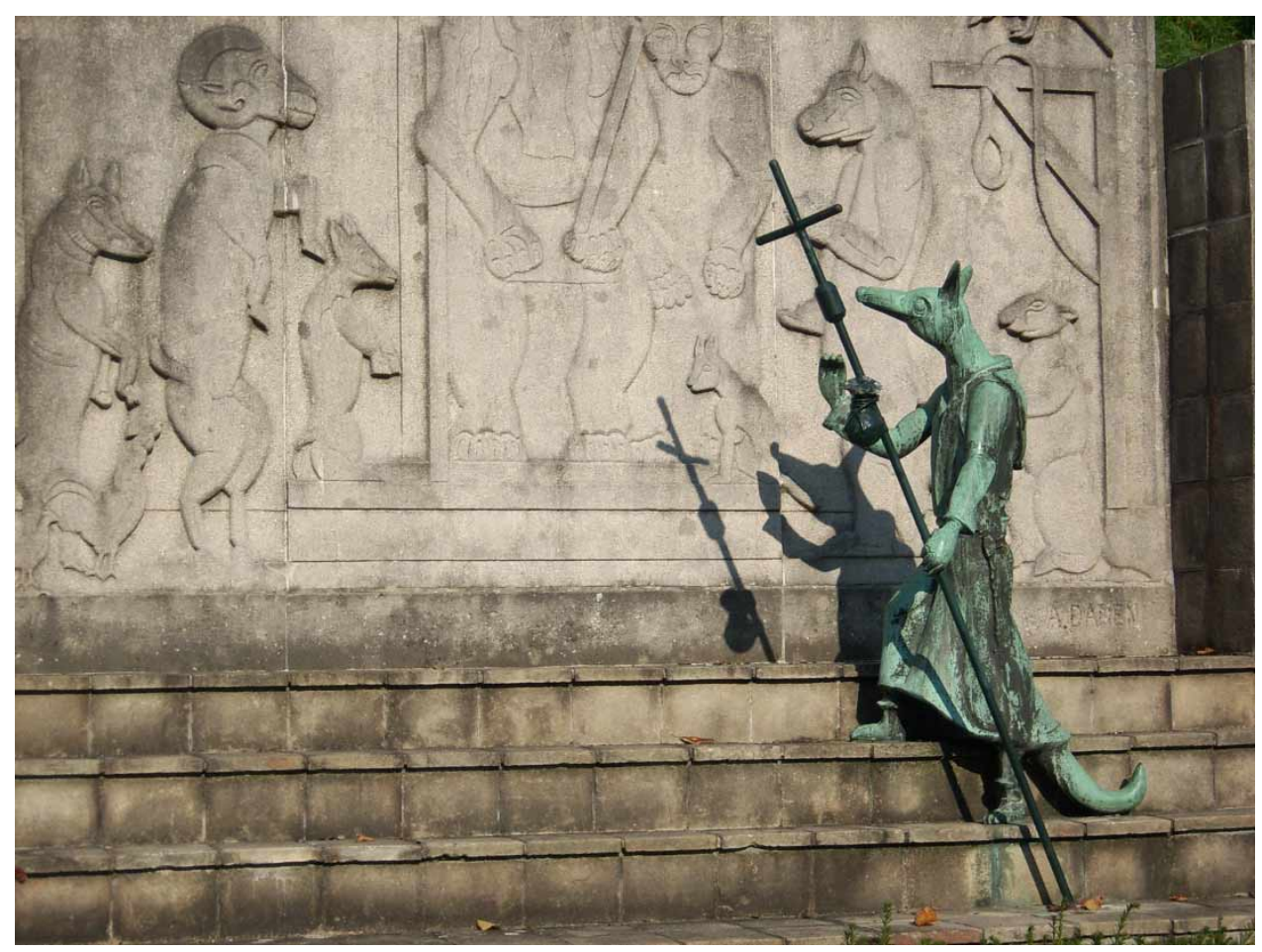

Figure 2. The statue of Reynard the Fox in Hulst. Photograph: Ruben A. Koman. 


\section{Best-known Dutch Legendary Icon: The Lady of Stavoren}

The Lady of Stavoren looks out over the waves from the harbour in Friesland. The statue dates to 1969 and, among the "legend statues," this is probably the best known (Figure 3). The legend itself, which later incorporated a version of ATU 736A The Ring of Polycrates (see Uther 2004), is very popular in the Netherlands.

It is hard to explain why this is such a popular narrative, but it has probably something to do with its gloomy kind of moralism. A rich female merchant living in the prosperous seaport town of Stavoren sends her shipmaster on a sea-journey in order to obtain the most precious thing in the world. The shipmaster returns with a beautiful load of grain. Disappointed, the Lady of Stavoren ordered that the load be thrown overboard. A beggar warned the woman that she should not waste the precious food, as she might be poor and hungry herself one day, but to no avail. The haughty woman took a gold ring from her finger, threw it into the sea, and said: "I will recover this ring sooner than I will become poor." To her amazement, when having dinner a few days later, she found her gold ring in a fish. Soon after, the woman was reduced to poverty and she lost her fleet and her worldly possessions. Then the seaport of Stavoren silted up and every year thereafter grain stems have sprouted in the harbour water.



Figure 3. The Lady of Stavoren. Photograph: Ruben A. Koman. 
The moral of the story corresponds to Dutch sayings such as "Wie het kleine niet eert, is het grote niet weerd" ["He who cannot appreciate small things, does not deserve valuable things"] [9] and "Hoogmoed komt voor de val" ["Pride comes before a fall"]. It is a sober and righteous - an almost Calvinistic - narrative about thrift and greed, virtue and sin, punishment and doom.

What applies to this legend, applies to many others also — there is hardly a grain of truth in it. The only true historical fact is that the harbour of Stavoren silted up in the late Middle Ages, but that happened well after the town had lost its commercial position to Antwerp and Amsterdam, whose harbours could berth larger ships. Part of the legend seems to be based on a misunderstanding. In the Middle Ages, Our Lady's Sand near Stavoren was the property of a convent-Our Lady being Saint Mary. After the demise of the convent, a fictional "Lady" was held responsible for the sandbank in front of the harbour. This is the oldest part of the legend, already told in the sixteenth century. The episode with the ring was added at the beginning of the nineteenth century.

\section{From Sinner to Acclaimed Hero: The Flying Dutchman}

The legends of Hans Brinker and the Flying Dutchman have one thing in common: they were both fabricated abroad. There is, however, one obvious difference between them. Hans Brinker was composed during the period of "Holland Mania" in the USA, which tended to praise Dutch moral standards, whereas the Flying Dutchman was composed by the British to expose Dutch morals as evil and God-forsaken. During the seventeenth and eighteenth centuries, the British and the Dutch competed fiercely on the high seas, a situation that led to three DutchBritish wars in the course of the seventeenth century.

At the end of the eighteenth century and at the beginning of the nineteenth century, ghost ships had already featured in English literature. In 1826 Edward Fitzball wrote a play called The Flying Dutchman, and in 1837 Frederick Marryat published a novel called The Phantom Ship. This latter work dealing with a doomed captain was translated into Dutch, and subsequently featured as a legend from the town of Terneuzen in a Dutch almanac of 1846.

In essence, the legend is about the captain of a VOC [10] trade ship, who sought to reach the East in a great hurry. His sins reportedly committed en route can vary considerably - he is said to have set sail on Easter Sunday, to have drowned a resisting helmsman, and, in most version, to have sold his soul to the devil in order to sail faster, even above the waves or against the wind. In the end, he loses his soul to the devil and, due to his greed and godlessness, he is doomed to sail the seven seas on board his ghost ship forever.

One would not expect with this kind of conduct on the part of the captain that an annual festival in his honour would be undertaken; yet, this is in fact what happens. Captain Van der Decken, the Flying Dutchman, is celebrated annually as a hero in the town of Terneuzen. In 1972 a monument to the Flying Dutchman was erected in the town, and, since 1984, Terneuzen has been called the "Town of the Flying Dutchman." An additional element of the Flying Dutchman Festival, in operation since 2006, is that one can even meet and greet the captain. In short, it seems that former negative (moral or religious) features of an original narrative 
can be easily ignored in the contemporary celebration of heroism, as is evident from this case. [11]

The claim Terneuzen makes on the Flying Dutchman character cannot be validated in any way. The harbour of Terneuzen was always much too small to be able to accommodate the large seventeenth-century sailing ships of the VOC; so it has no connection whatsoever with this type of vessel or trade. We are, however, dealing here with imagined heritage, not with history; so nobody cares about genuine historical facts. The Flying Dutchman has turned into a cultural icon that (albeit for just a short period of time each year) fosters a feeling of togetherness and belonging among the inhabitants of Terneuzen, and which also provides the town with an attractive legendary and powerful profile for the outside world.

\section{Confiscated by Koudekerke: The Mermaid of Westenschouwen}

A legend about the village of Westenschouwen in Zeeland, and about fishermen from the town catching a mermaid, has been recorded from oral tradition since the nineteenth century. According to this legend, the husband of the mermaid demanded her return in vain, and then uttered the following curse (in rhyme): "Westenschouwen, you will be sorry for taking my wife. Westenschouwen will perish; only the blunt tower will remain."

This legend, like that of the Lady of Stavoren, explains, retrospectively, the decay of late-medieval Westenschouwen. In fact, the harbour of Westenschouwen was already silted up in the fifteenth century, and, after some eighteenth-century floods, the village itself fell into the sea, with only the roofless tower remaining erect above the water. The tower was sold in 1845, and was torn down in 1848 in order that the bricks could be re-used elsewhere. With the tower in Westenschouwen gone, the neighbouring village of Koudekerke availed itself of the chance to appropriate and adapt the mermaid legend for its own existing tower. So with the confiscation of the legend by the village of Koudekerke, the mermaid legend of Westenschouwen basically migrated from a destroyed tower to a nearby existing one.

In 1997, this blunt tower of Koudekerke was turned into a tourist attraction. A revolving display inside the tower depicts the legend of the mermaid of Westenschouwen, while a sound recording combines the story of the fall of Westenschouwen with the story of the existence of the tower of Koudekerke. So with the transference of the legend to the tower of Koudekerke a new lieu d'imagination (place of imagination) has been recreated (see Reijnders 2010, 3-5, 7-8 and 12).

\section{Commercial Appropriation: The Legend of the White Women's Pit}

There is one man in Zwiep (Gelderland) who has a particular reason for revitalising and cultivating the legend of the White Women's Pit. This is the local miller and baker Gé Postel, who bakes the local White Women's Cake, often mentioned in the legend. He has built a little theme park with a shop, a restaurant, and a garden full of handmade dolls-demonic White Women, of course, but including witches and other beings as well-around the legend and the cake. In the summer season, there is also a storyteller on hand, who, after dinner, takes the guests to the nearby White Women's Pit and narrates the legend associated with it. 
The legend is, in effect, a love story, in which a girl prefers a poor farmer's son, but is forced to marry a rich farmer's son. The poor farmer's son is devastated and almost falls into the White Women's Pit, but one of the women pushes him out. In order to express his gratitude, he brings the White Women a cake on a plate the next day. Sometime later there is a suitors' test-both lovers have to show their courage by throwing a whetting anvil into the White Women's Pit. The rich suitor proves to be a coward, but the poor suitor throws the whetting anvil into the Pit and has to run for his life, as the howling White Women are at his heels. He manages to reach home and to close the door just before the White Women catch up with him. He is allowed to marry the girl. The White Women give them a wedding gift of a plate and a whetting anvil in solid gold in recognition of the poor man's gratitude and courage. So the demons were not so angry after all, and the couple ended up rich in the end.

There are some old motifs in the legend, such as the haunting by the White Women and the wager to throw a whetting anvil into the pit. However, the romantic plot involving the two lovers was composed by the famous Dutch local poet, A. C. W. Staring (1767-1840). The folktale-type details such as the suitors' test, the obtaining of a bride, the present of gold objects, and the happy ending in which "love conquers all," are additions by Staring. For baker Postel's use, the story required hardly any adjustments: the only thing that needed to be done was that the cake had to be called "White Women's Cake." It is not uncommon for the well-developed and better-known Dutch legends to have been created by authors and to have been invented in the nineteenth century.

\section{Invented Legend: The Gnome of the Peel}

Dutch tales of the little people can be old and are to be found all over the country, especially in the southern provinces of North Brabant and Limburg. In stark contrast to that, the legend of the Gnome of the Peel was invented and published in 1996 by Mayor Romé Fasol of Horst. This is a story in which the people of Horst help the gnomes to go and live underground, while the gnomes teach the people how to grow mushrooms. A year after the legend's invention, the Mayor and Council decided to erect seventeen small bronze statues with scenes from the story, sponsored by local government and shopkeepers. The legend was an obvious invention of tradition-the town of Horst wanted to give itself a specific presentation by creating a quasi-historical form of heritage. The story, however, had too many modern, literary, and dull features to be able to stimulate tourism or to improve the image of local mushroom cultivation. The goal to strengthen local identity with a new legend and associated sculptures did not succeed. Given the success of using an existing traditional legend (literary if need be) for promotional purposes in other cities, it would seem that that approach is to be preferred over devising a brand new legend for identity purposes.

\section{Two Communities Claiming the Same Legend of Kiste Trui}

He who owns a good narrative may possess gold. The more a story is known, the better for those who appropriate it. Pertinent examples of this from abroad are narratives connected to Robin Hood in England and Dracula in Romania. Because the stories are well known internationally, several communities may lay claim to 
their characters. Dracula tourism is still developing in Romania, with many places in the country claiming to have had some connection to the famous count, and they try to profit from the resultant expanding tourism. [12] In England, tourism surrounding the legendary figure Robin Hood is well developed and lucrative, with the result that communities in a wide area around Sherwood Forest compete in an attempt to own (a piece of) the story. [13]

Such obvious rivalry and struggle over a legend rarely happens in the Netherlands. The appropriation of the legend of the mermaid of Westenschouwen by Koudekerke occurred without protest. The most obvious case of a dispute over a local legend took place in 1977 in the town of Mook in Limburg, when Mook wanted to erect a statue to Kiste Trui, a legendary character claimed by the smaller neighbouring community of Middelaar (Figure 4).

The legend revolves around the historical fact of the Battle on the Mookerhei between Dutch Reformed Protestant troops and the Spanish Catholic army in 1574 during the Revolt against the kings of Spain (1568-1648). Many soldiers died and a rumour circulated that a hidden chest with soldiers' pay was left behind. One woman living in Middelaar got so obsessed about finding this chest of gold that she dug for it daily at the battleground location. She was even nicknamed

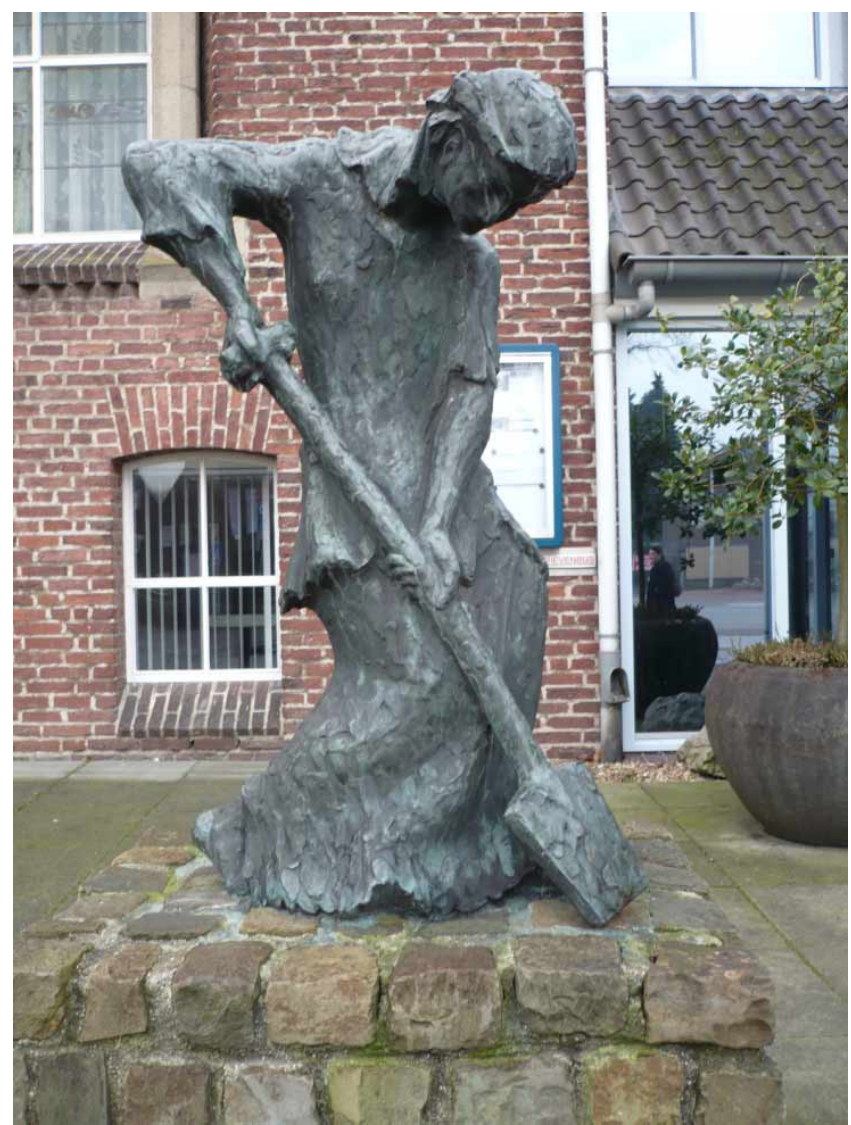

Figure 4. The statue of Kiste Trui in Mook-Middelaar. Photograph: Eric Venbrux. 
"Kiste Trui" ["Treasure Trudy"]. She dug and dug throughout her life, but she never found her sought-after treasure.

Mook village depends mainly on tourism and recreation, and in the second half of the twentieth century the Tourism Bureau (along with the local government and a number of pubs) saw the possibility of making profit from the exploitation of the legend. In 1976 the Tourism Bureau started selling little statues of Kiste Trui, and in 1977 a larger statue of her was placed next to the town hall of Mook. Rivalry between Mook and Middelaar had always existed, and the latter community protested to Mook that Kiste Trui was theirs. A plan to steal the statue during the night before it was unveiled failed. In the end, a protest demonstration was held during the ceremonial unveiling of the statue. One protest board read: "If Treasure Trudy had known [that this would happen], she wouldn't have wasted her time."

The oldest recorded version of the legend dates from 1875. At first, the legend lived only a paper life in legend books. This changed after the Tourism Bureau started exploiting the legend, as it then became part of daily life and returned once more to the oral tradition where it had originated.

\section{An Open Air Museum with the Legend of Ellert and Brammert}

The legend of Ellert and Brammert was recorded in the seventeenth century by the Revd Mr Johan Picardt (1600-1670) in his book on the history of the province of Drenthe. In his version of the story, a father named Ellert, and his son named Brammert, were robbers, and lived in a hole in the ground. They usually robbed and killed travellers, but one day they kidnapped a girl and abused her for several years. The children she bore were murdered. One day, in the absence of the son, the girl slit the throat of the sleeping father and successfully fled the scene. She subsequently revealed the many crimes that the father and son had committed. Two elements in the landscape are still named after the robbers- "Ellertsfield" and "Brammertsheap."

In reality, however, the situation was quite different. As the place names "Ellertsfield" and "Brammertsheap" were no longer understood, a tale about robbers was composed to explain them. There are several megalithic tombs in the province of Drenthe, which are called hunebedden ["giants' beds"]. The Revd Picardt was convinced that giants had actually made these tombs in the earliest times of Christian history. Although Picardt in his book on the history of the province of Drenthe never made a connection between Ellert, Brammert, and the giants, this has happened in twentieth-century versions of the story, in which the robbers turn into giants.

So the story changes and expands over time. The giants are said to stretch out cords over the heathland, and thus every time travellers pass by, they are alerted to their presence by a bell in their hole (ATU 965*, Robbers' Alarm Bell; see Uther 2004). The girl they abducted is given the name Marieke of Orvelterveen. In order to make the legend less horrible (especially for children), narrators keep silent about the rapes and infanticides associated with the original female character. She is thus described as a slave, she has to do the housekeeping, and she is continually beaten. While shaving the son, Brammert, she cuts his throat and flees, but the father, Ellert, pursues her. She reaches home and manages to keep Ellert from 
entering the house- the axe he throws ends up in the door. The giant dies in despair. The places of their deaths are called "Brammertsheap" and "Ellertsfield."

Ellert and Brammert got more than a statue-they got an entire Open Air Museum (Ellert en Brammert museum) in the village of Schoonoord in Drenthe, a place that calls itself the village of giants. No other legend in the Netherlands has been the subject of musealisation to the same extent as that of Ellert and Brammert. In fact, the giants are considered to be a brand mark for the identity of the entire province. On the other hand, the museum cannot live by Ellert and Brammert alone. While images of the giants stand near the entrance of the museum, and their hole in the ground has also been reconstructed in the museum, the rest of the display is mainly concerned with regional history - with turf huts, a reconstruction of a megalithic tomb, an old school, and an exhibition about peat-cutting. In the old school, a hired professional storyteller regularly retells the legend to tourists.

\section{Even Sarcastic Legends Will Do: The Ray Stabbers of Weert}

It is a rather strange phenomenon that in many places a negative nickname has been appropriated and used in an honorary fashion. Neighbouring communities often invent negative nicknames in order to ridicule or insult each other. These nicknames are meant to mock the others by implying that they are insignificant, poor, uncivilised, aggressive, criminal, or incredibly stupid. In several cases, these nicknames come with a matching legend.

One of the oldest sarcastic nicknames used for the inhabitants of Weert in Limburg is "Ray Stabbers." Both the nickname and the story have been known since the seventeenth century. In short, the story is about a fishmonger losing a ray from his cart. The people have no idea what this monster is, and suppose that it is some kind of a demon that needs to be killed right away, but no one is brave enough to do the deed. Most of the time, the story ends with the fishmonger returning and throwing the ray back onto his cart, and laughing loudly at the stupidity and cowardice of the people of Weert.

In the nineteenth and twentieth centuries, the nickname "Ray Stabbers" was incorporated into the local culture of Weert. The town carnival club, for instance, is called the "Ray Stabbers," and during carnival the town turns into "Ray Stabbers City." Those who had participated in the carnival procession donated a "Ray Stabbers Monument" to the city in 1986.

The appropriation of abusive nicknames and sarcastic legends and turning them into superior forms of self-mockery is, for example, a means by which to neutralise the offensive aspect of the names, especially in an atmosphere of the (temporary) amusing reversal of values.

\section{Legend Tripping: The Haunted Farm of Brummen}

Every time people leave their homes in order to experience a legend, this can be called "legend tripping." When this has been organised by the tourist industry, most of the time one is dealing with a guided tour, directed from above. In the eastern part of the Netherlands, one can experience so-called "legend safaris" tourists rent a GPS device and drive from location to location and hear the matching legends. There are, however, forms of legend tripping without any external guidance. This is the case when, for example, youngsters decide to pay a 
so-called haunted house a nighttime visit in order to experience some horror, to play ghost hunter, to act out satanic rituals, to find out if there really is something between heaven and earth, or to test each other's nerve, loyalty, and friendship.

Farm Dijkzicht in Brummen (Gelderland) has the reputation of being a haunted farm, mainly because it has been uninhabited for a long period of time. According to the associated legend, a father disapproved of his son's girlfriend. When he obstructed the marriage, the son hanged himself on a nearby tree. His ghost was said to have returned to haunt his father. Eventually, the father moved away, but the son continued to haunt the place, and this is the reason why nobody dares to live on the farm anymore.

Tenants who use the barn as a stable, and the neighbours, have never experienced any haunting episodes, but they did have problems with (drunk) youngsters who came hunting for ghosts in the dead of night. For a while, the socalled haunted farm was added to a legend route and busloads of tourists tended to stop there in the daytime. One neighbour even put up a sign on her door saying: "No ringing for ghost stories." Every time the media reports on the ghost farm, the number of legend trippers increases. The Internet is an important source of information these days. Examples of ghost stories and discussions about them can be found in various online fora, and short ghost movies and documentaries made by journalists, ghost hunters and psychics, can be found on YouTube. [14] It is sometimes admitted in Internet discussions that knowledge of the spooky legend substantially contributes to the level of creepiness of a nighttime legend trip-in folklore, this phenomenon is called "quasi-ostension"; that is, knowledge of the legend influences the perception and interpretation of reality, as well as the behaviour of the people present. It is not so much the so-called real events that necessarily give participants the creeps, but the stories that they have read concerning them.

\section{The Legend as Spectacle: Dragon-slayer St George}

If a legend functions anywhere as a unifying element, it is surely in the village of Beesel in Limburg that this occurs. Here, every seven years, the legend of Saint George and the Dragon is acted out as a spectacle, several times in the course of a summer. A director is hired from abroad and hundreds of the inhabitants of Beesel-a substantial part of the community-participate in the play as extras, while a few get chosen as actors. Both the procession in the daytime and the play in the evening attract a growing number of visitors; in order to view the play, seats need to be booked and admission tickets have to be bought. As far as placebranding with legends goes, this is the best example of what Gregory J. Ashworth calls "event hallmarking" (Ashworth 2009, 18-20).

The story is the traditional legend of Saint George rescuing the princess and slaying the dragon. In a Christian sense, the legend tells of the battle between the saint (good) and the devil (evil). The older, more orthodox Catholics complain that, today, the religious dimension is disintegrating at the cost of action that has little to do with the original legend, but which is added in order to captivate a modern audience. Technical innovation makes the play even more spectacularsince 1995, the fourteen-metre-tall dragon can not only move its head, eyes, tail, and wings, but also roar, and blow smoke and fire. 
The dragon has become a unifying element in the community of Beesel-the monster (and not St George) can even be found in the town's coat of arms.

\section{An Authentic Legend from the Wadden: The Woman of Stryp}

Sooner or later people will ask a Dutch folklorist for a typical example of a Dutch legend. This is hard to provide, as there are hardly any typical Dutch legends. All oral material is part of an international repertoire, regardless of borders or languages. Of the legends treated in Verhalen van Stad en Streek, almost all have a broader geographical distribution than the Netherlands, and almost none have an exclusively Dutch origin. The urban legend of the wandering quilt, full of maggots, may have been originally Dutch, but the story has spread beyond the Netherlands at this stage (Burger 1993, 143-4). Another example is the urban legend about a dog being put down after attacking a child, but when the vet examines the dead dog he notices twenty-seven staples in the dog's ear (Burger 2006, 165-7).

A traditional legend that is localised to such extent that it remains in its area of origin comes from one of the Wadden Islands called Terschelling-a relatively isolated place. The story refers to the Second Dutch-English War when British troops invaded West-Terschelling in 1666 in order to plunder and burn down the storehouses of the States of Holland and of the trading company VOC. While West-Terschelling was burning, the inhabitants fled to its eastern part for safety. This part of the story is historically correct, but what follows is legend. One of the British leaders was said to have ordered his soldiers to plunder the eastern part of Terschelling. As they approached the cemetery of Stryp, the soldiers stopped, as they thought they saw Dutch soldiers ready to ambush them in the distance. What they were really looking at were scattered headstones. One of the soldiers asked an old woman who was passing by what was happening in the distance. The Stryper Woman answered sharply: "They stand there by hundreds, but they lie there by thousands." She meant, of course, headstones and the dead, but the British were scared, because they thought that the woman meant armed enemies. The soldiers turned around and, thanks to the remark of the Woman of Stryp, the east of Terschelling was spared (Figure 5).

The heart of the legend is in this one sentence: "They stand there by hundreds, but they lie there by thousands." It is hard to tell why this (unintentional) stratagem has never been used elsewhere in the Netherlands or abroad. Although the isolated position of the island may serve as an explanation, it is still much visited by tourists. In 1982, a bronze statue was erected to the Woman of Stryp. It looks as if some legends from the Wadden have not travelled from the island, [15] while other legends are definitely known elsewhere also. [16]

\section{Contemporary Legends: No Pride, No Claims, No Statues}

Most of the traditional legends mentioned in this paper have one thing in common: groups of people somehow take pride in this kind of local non-material heritage. Statues are erected, feasts, festivals or other activities are organised based on the legend. This pride of place does not incorporate urban legends-modern crime legends, for example, are just not claimed by communities.

In 2002, a rumour went about that a child had been abducted from the ball pit in IKEA Delft (South Holland). The mother managed to find her daughter just in 


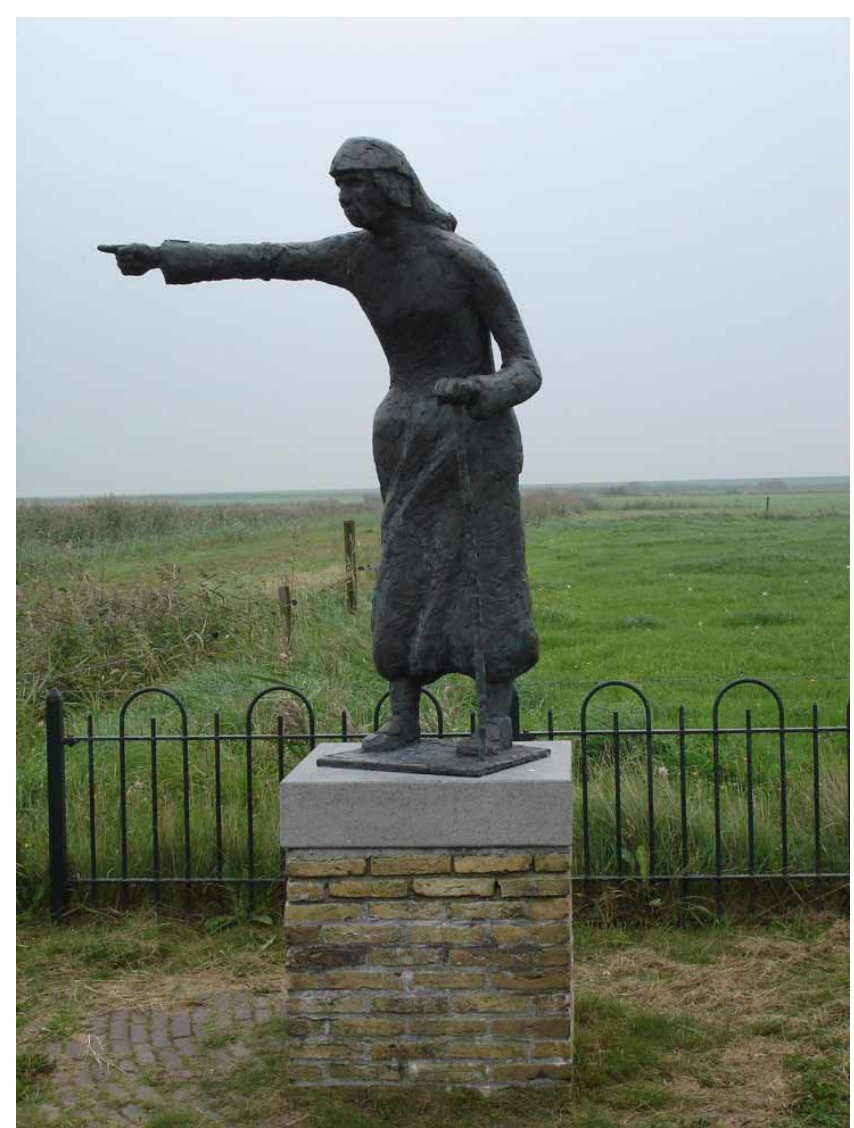

Figure 5. The Statue of the Woman of Stryp. Photograph: Loes Hendriks.

time, as her hair had been cut off, she had been drugged, and she had had a change of clothes. She was ready to be smuggled away by some Poles and, after that, God knows what would have happened to her. The story has been told about every branch of IKEA in the Netherlands, and about theme parks like the Efteling and Disneyland Paris. The town of Delft version of the legend was a random choice for Verhalen van Stad en Streek, as we just wanted to include some contemporary legends in the book as well.

In 2003, the grim legend of the Smiley Gang hit the Netherlands (see also Burger 2009). A gang of Moroccans or West Indians allegedly stopped a girl walking alone in the night in order to make her choose between a group rape and a smiley. When she chose a smiley, they cut the corners of her mouth from ear to ear. This situation never actually happened and the legend mainly reflects people's fear of young, delinquent immigrant boys. The legend as associated with the city of Leiden is just one of the examples we took, but again, it is not a story to be proud of.

Perhaps the most painful example we selected was the legend concerning mass hysteria that arose in 1987, concerning the supposed paedophile clowns from Oude Pekela (Groningen). The clowns were supposed to drive around in a white van and sexually abuse children. Testimonies about such abuse came not only 
from parents, but also from nursery school teachers, a couple of family doctors, and a psychiatrist. The supposed number of victims grew rapidly and, at the peak of the moral panic, some people suggested that Satanists were involved. Police investigations did not find any evidence of clowns or of abuse, only a lot of worried parents.

As we have seen in this paper, traditional legends touch on topics concerned with the past; that is, things of bygone times that now appeal to collective feelings of nostalgia and oneness. No one takes offence at the old witch and devil tales, the nicknames, and the old wives' tales anymore. Contemporary legends, however, still strike a raw nerve. Because they can voice present and future fears and prejudices, communities may prefer to keep them quiet. It will take a long time (if ever) before these modern legends (in altered form?) can serve as a form of common heritage like traditional legends do now.

\section{One Exception: A Sculpture for the Contemporary Legend of Winnie the Puma}

There is, however, one exception to this to be found in the Netherlands-a work of art in memory of Winnie the Puma. This is the puma that many people spotted during the summer of 2005, but which no one managed to catch-because most people saw something else, most likely a large cat.

The artist Maarten de Reus created a sculpture for the Vellertheuvel in Apeldoorn (Gelderland) called "Cage-with-no-puma-in-it." It is a construction of steel wire, which, from a distance, shows a puma in a cage, but the puma fades away the closer you get to the cage (Figure 6). During the presentation of this work of art in 2008, the local pop group Springvloed sang their "Puma Song" .

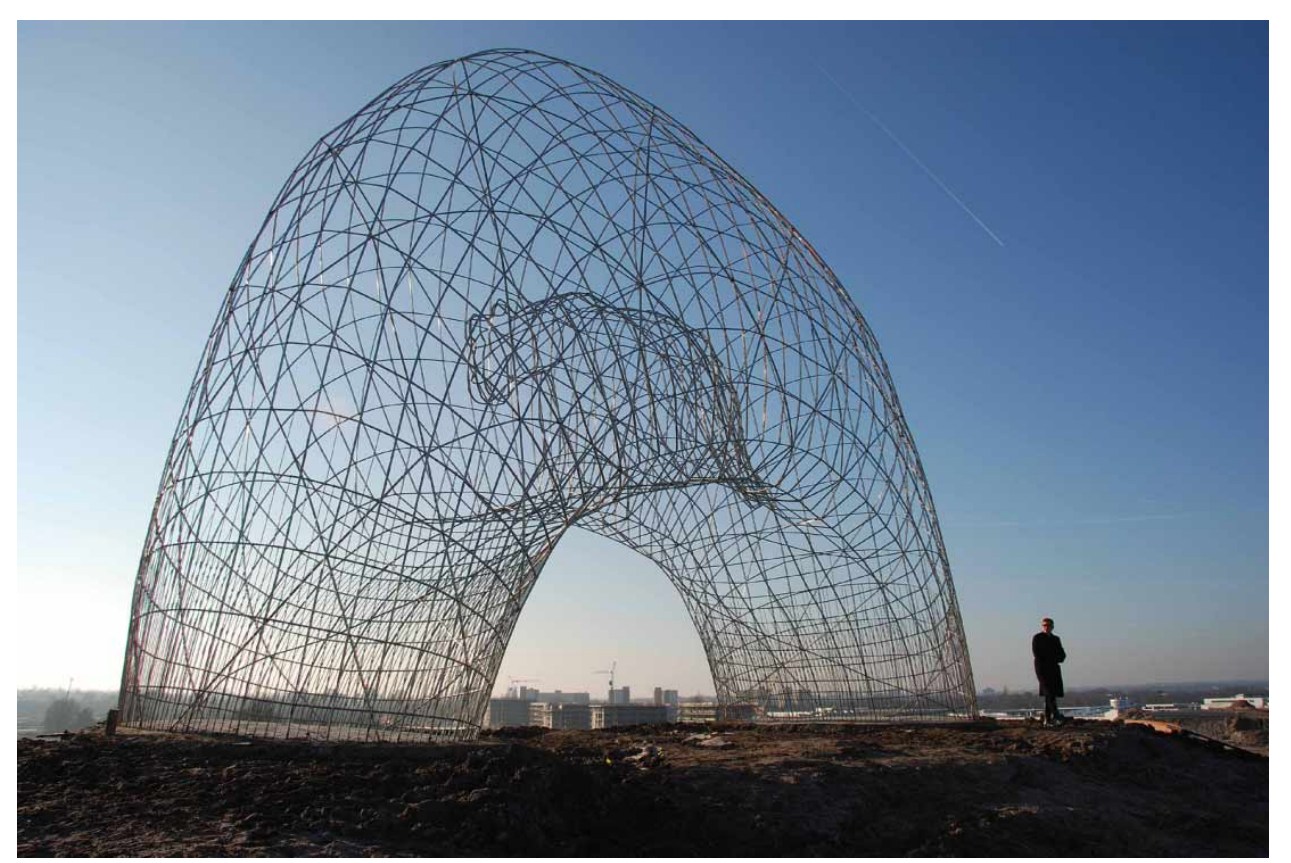

Figure 6. Sculpture for Winnie the Puma called "Cage-with-no-puma-in-it." Photograph: Maarten de Reus. 
The reason why this statue obviously does not strike a raw nerve is that the Puma incident was generally thought of as being more amusing than painful. It may take a while before another urban legend is turned into a public piece of art.

\section{Conclusions}

Traditional legends in particular can adapt to locality and situation in order to create solidarity and a shared identity, even if this creation of identity is temporary - as occurs during carnival, for instance. Apart from a single exception, modern legends are not (yet) accepted for the purposes of shaping identities on a level of location, district, village, town, or region. If modern legends define identities, it is rather on a level of age, subgroup, gender, and ethnicity.

Certainly, not all places have appropriated a legend. Most places in fact have not. It was possible, nevertheless, to find legends connected with places, in oral tradition, and particularly in local and regional legend books. Some places have chosen to have a legend shape part of their identity, be it casually or emphatically. Mostly, the decision to appropriate a legend comes from "above"; that is, from local government, the local historical society, the tourism bureau, or the local bank and shops. At least the initiative usually starts on that level. It is not necessary that the legends be very positive ones, as even mocking or negative stories can be adopted, as we have seen above. Furthermore, stories are always flexible; thus function and meaning can be altered-a sinner can turn into a hero with ease. The motivation behind the appropriation of a legend in the case of the Netherlands has mostly to do with the sphere of tourism and commerce, with internal solidarity, or with self-representation to the outside world. The legend can be promoted as heritage and enter the local canon; a certain character can turn into a local icon. If a place makes a serious effort in the promotion of a legend, it can be used in the folkloristic and museological domain, during festivals, for commercial purposes, or even in the dramatisation of the story. In instances where more than one place lays claim to a tale, competitive rivalry can occur. Most places tend to claim a legend exclusively-the fact that legends can be ecotypes, and part of an international corpus of variations, is not a popular message for those who appropriate them. Apart from a few minor exceptions, the legends are not originally or exclusively Dutch, let alone local. Claims that legends are age-old can scarcely be proven, as far as the Netherlands is concerned. In fact, many legends seem to be nineteenth-century constructions or even more recent inventions of tradition. Once mainly a lower-class preoccupation, the recreational, commercial, and identity-shaping interest in traditional legends has now shown a paradigm shift towards high-class and middle-class culture (compare Lyth 2006).

\section{Notes}

[1] This article is a reworking of the paper presented at the 28th International Conference of the International Society for Contemporary Legend Research, held in Amsterdam, 28 June-1 July 2010.

[2] Apart from the four editors, eleven authors participated in this publication.

[3] See De Blécourt et al. (2010). 
[4] The editors decided to limit the number of legends included, and to present more in-depth research in respect of each. We also tried to achieve a representative distribution of tales and themes. Nevertheless, it was inevitable that a greater number of legends about saints would be selected for the Catholic provinces of North Brabant and Limburg in the south, than for the Protestant north of the Netherlands.

[5] All of the cases presented in this paper are derived from De Blécourt et al. (2010). As this book has attempted to deal with the scholarly literature on the topic as comprehensively as possible, only recent or recently-discovered articles on the subject will be mentioned here. Fairytale theme parks such as De Efteling (Kaatsheuvel, North Brabant) and Sprookjeswonderland (Enkhuizen, North Holland) are disregarded in this paper, although on a level of tourism or commerce they are extremely important. In Verhalen van Stad en Streek, these fairytale theme parks are treated under "Kaatsheuvel" (see De Blécourt et al. 2010, 504-7).

[6] Mapes Dodge had not been to the Netherlands at the time when she wrote the story, and her Dutch informants in the USA, the Scharff couple, would not have told her the story either.

[7] A second and different statue of Hans Brinker was placed in the harbour of Harlingen in Friesland in 1962. In 2006, a statue was erected to Hans Brinker in The Hague, near the entrance of Madurodam, a miniature representation of the Netherlands aimed at tourists. Finally, in 2008, Hans Brinker appeared as a Dutch icon on a Delftware paintbrush by artist Hugo Kaagman in Zuiderzeemuseum, the Open Air Museum at Enkhuizen (North Holland).

[8] Ashworth (2009) shows three strategies for place-branding, one of these being "personality association," as in the case of Reynard.

[9] The English equivalent is: "Who will not keep a penny, never shall have many" (Cox 1988, 281).

[10] VOC, "Verenigde Oostindische Compagnie," the Dutch East Indies Company.

[11] Perhaps it is fair to say that the Flying Dutchman is also a (somewhat atypical) hero in the second and third parts of the movie Pirates of the Caribbean.

[12] Some Dracula legends are, in one way or another, connected to the novel by Bram Stoker dating from 1897 (Stoker 1897), so they are of literary origin. Other Dracula stories are based, to some extent, on the historical Vlad III, Prince of Wallachia (1431-1476). Romania and Transylvania have sought to avoid or reluctantly tolerate Dracula tourism in the past for fear of being perceived as becoming too closely associated with superstition and horror (see also Light 2007; Koman 2010).

[13] This legendary figure is claimed for several places in the counties of Nottinghamshire and Yorkshire, most prominently for Sherwood (Forest)/Nottingham, Loxley/Sheffield and Wakefield/Barnsdale. See the Index in Westwood and Simpson (2005) under "Robin Hood," and see Lyth $(2006)$ and Ashworth $(2009,12)$. In the Netherlands, the journalist Reggie Naus is trying to stimulate the exploitation of the relatively unknown legends about a local robber named Jacobus van der Schlossen for Ravenstein (North Brabant), in order to make him as famous as Robin Hood.

[14] The Dutch Wikipedia once proclaimed the haunted farm of Brummen as one of the six most famous paranormal places in the Netherlands, but this entry was subsequently deleted. Now there is a more neutral wiki page on hauntings that mentions the farm in a list of ten haunted houses; see http://nl.wikipedia.org/wiki/Spookhuis; INTERNET [accessed 28 October 2010].

[15] The Syrup Pot from Texel, for instance; see De Blécourt et al. (2010, 364-5).

[16] Rixt van 't Oerd from Ameland; see De Blécourt et al. (2010, 67-9). 


\section{References Cited}

Anonymous. “The Little Dutch Hero.” Boy's Own Magazine 1 (1855): 292-3.

Ashworth, Gregory J. "The Instruments of Place Branding: How is It Done?" European Spatial Research and Policy 16, no. 1 (2009): 19-22.

De Blécourt, Willem, Ruben A. Koman, Jurjen van der Kooi, and Theo Meder. Verhalen van Stad en Streek. Sagen en Legenden in Nederland. Amsterdam: Bert Bakker, 2010.

Burger, Peter. De Wraak van de knagoeroe. Amsterdam: Prometheus, 1993.

- De jacht op de Veluwepoema. Sagen en geruchten uit het moderne leven. Amsterdam: Prometheus, 2006.

- "The Smiley Gang Panic. Ethnic Legends about Gang Rape in the Netherlands in the Wake of 9/11." Western Folklore 68, nos. 2/3 (2009): 275-95.

Clements, William J., ed. “Oikotype/Oicotype." In Folklore. An Encyclopedia of Beliefs, Customs, Tales. Music and Art, ed. Thomas A. Green. Vol. 2. 604-5. Santa Barbara, CA: ABC-CLIO, 1997.

Cox, H. L. Spreekwoordenboek in vier talen. Utrecht [etc.]: Van Dale Lexicografie, 1988.

Dodge, Mary Mapes. Hans Brinker or the Silver Skates. New York: James O'Kane, 1865.

Koman, Ruben A. "Roemenië zet zijn tanden in oude en moderne verhalen: het Draculatoerisme als booming business." Vertel eens... 5, no. 2 (2010): 14-19.

Light, Duncan. "Dracula Tourism in Romania. Cultural Identity and the State." Annals of Tourism Research 34, no. 3 (2007): 746-65.

Lyth, Peter. "Selling History in an Age of Industrial Decline: Heritage Tourism in Robin Hood County." Paper presented at the XIV International Economic History Congress, Helsinki, 21-25 August 2006.

Reijnders, Stijn. "Places of the Imagination: An Ethnography of the TV Detective Tour." Cultural Geographies 17, no. 1 (2010): 37-52.

Simpson, Jacqueline. "Seeking the Lore of the Land." Folklore 119, no. 2 (2008): 131-41.

Stoker, Bram. Dracula. London: Archibald Constable and Company (UK), 1897.

Stott, Annette. Holland Mania. The Unknown Dutch Period in American Art and Culture. Woodstock, N.Y.: The Overlook Press, 1998.

Uther, Hans-Jörg. The Types of International Folktales. A Classification and Bibliography. Parts I-III. FFC 284-6. Helsinki: Academia Scientiarum Fennica, 2004.

Von Sydow, Carl. W. “Geography and Folk-tale Oicotypes." In Selected Papers in Folklore, ed. Laurits Bødker. 44-59. Copenhagen: Rosenkilde and Bagger, 1948.

Westwood, Jennifer, and Jacqueline Simpson. The Lore of the Land. A Guide to England's Legends, from Spring-Heeled Jack to the Witches of Warboys. London: Penguin Books, 2005.

\section{Biographical Note}

Theo Meder is a folk narrative researcher at the Department of Ethnology of the Meertens Instituut in the Netherlands. He specialises in Dutch folktales and supervises the Dutch Folktale Database. His interests range from identity, ethnicity, appropriation and the supernatural, to repertoires, performances, ostension and virtual storytelling. 